Monika Kavalir

Oddelek za anglistiko in

amerikanistiko

Filozofska fakulteta Univerze v Ljubljani

monika.kavalir@ff.uni-lj.si
UDK 81'25:[811.111'367.623:811.163.6'367.623]

DOI: $10.4312 /$ vestnik.8.75-98

\title{
UČINKI TRANSFERJA PRI ABSOLUTNI IN RELATIVNI RABI PRIDEVNIKOV MED SLOVENSKIMI ŠTUDENTI ANGLEŠČINE
}

1 UVOD

Ko se pri učenju tujega jezika povzpnemo na stopnjo »učinkovitega uporabnika« oz. na »raven učinkovitosti« in »mojstrstva«, kot ravni C1 in C2 opredeljuje Skupni evropski jezikovni okvir (2011), se približujemo maternim govorcem in razlika med našim »medjezikom« (interlanguage; npr. Tarone 2006) in ciljnim jezikom se zmanjšuje, predvidoma na vseh področjih. Pri tem je lahko v pomoč tudi izrecno opozarjanje na medjezikovne razlike, ki se pokažejo skozi protistavni jezikoslovni pristop, in ozaveščanje možnosti, da pri teh divergentnih značilnostih prihaja do medjezikovnega vpliva, ki ga imenujemo interferenca oz. negativni transfer (npr. James 2012) pri prenosu jezikovnih strategij.

Takšno do zdaj le redko obravnavano področje slovničnih razlik med slovenščino in angleščino je absolutna in relativna raba pridevnikov. ${ }^{1}$ Raziskava M. Kavalir (2014) je pokazala, da je mogoče v okviru sistemsko-funkcijskega pristopa (npr. Halliday in Matthiessen 2014) stopnjevanje pridevnikov v obeh jezikih obravnavati po istih kriterijih, tako da se ločita podsistem stopnje (osnovna, srednja in visoka) ter podsistem standarda (notranji proti zunanjemu), kjer se slednji nanaša na to, ali so za interpretacijo pomena potrebne informacije zunaj jezikovne enote, natančneje ali je pomen pridevnika odvisen od samostalniškega nanosnika ali ne. V obeh jezikih sta podsistema v celoti povezljiva, kot kaže naslednji pregled vseh kombinacij:

1 Študija se tako pridružuje raziskavam drugih področij slovensko-angleške protistavne analize (v zadnjem času npr. Ilc 2014, Jurko 2016, Komar 2012, Lipovšek 2014, Pisanski Peterlin 2010, Plemenitaš 2015, Sicherl 2013, Vrbinc 2016, Zlatnar Moe 2010) in širše prisotnosti kontrastivnega jezikoslovja v slovenskem prostoru (nedavno npr. Schlamberger Brezar, Limon in Gruntar Jermol 2016, Lovec 2016, Mikolič 2012, Vaupot 2016). 


\begin{tabular}{|l|l|l|l|}
\hline & \multicolumn{1}{|c|}{ Osnovna stopnja } & \multicolumn{1}{c|}{ Srednja stopnja } & \multicolumn{1}{c|}{ Visoka stopnja } \\
\hline $\begin{array}{l}\text { Zunanji } \\
\text { standard }\end{array}$ & $\begin{array}{l}\text { ANG: Mary has a big dog. } \\
\text { SLo: Marija ima velikega } \\
\text { psa. }\end{array}$ & $\begin{array}{l}\text { ANG: She chose a nicer/more } \\
\text { extravagant ring than he } \\
\text { originally suggested. } \\
\text { SLo: Izbrala je lepši/bolj } \\
\text { ekstravaganten prstan, kot } \\
\text { ga je predlagal on. }\end{array}$ & $\begin{array}{l}\text { ANG: Luxembourg is the } \\
\text { richest/most advanced EU } \\
\text { country. } \\
\text { SLo: Luksemburg je } \\
\text { najbogatejša/najbolj } \\
\text { razvita država EU. }\end{array}$ \\
\hline $\begin{array}{l}\text { Notranji } \\
\text { standard }\end{array}$ & $\begin{array}{l}\text { ANG: His grandfather is a } \\
\text { kind man. } \\
\text { SLo: Njegov dedek je } \\
\text { prijazen človek. }\end{array}$ & $\begin{array}{l}\text { AnG: All better hotels offer } \\
\text { self service. } \\
\text { He explained some of his } \\
\text { more radical ideas about } \\
\text { afterlife. } \\
\text { SLo: Vsi boljši hoteli nudijo } \\
\text { samopostrežne obroke. } \\
\text { Njegove ideje o posmrtnem } \\
\text { življenju so bolj temačne. }\end{array}$ & $\begin{array}{l}\text { Ang: Alan bought her the } \\
\text { cutest little bouquet. } \\
\text { Alan bought her a/the } \\
\text { most wonderful little } \\
\text { bouquet. } \\
\text { SLo: To bom storila z } \\
\text { največjim veseljem. } \\
\text { Kupila je obleko iz najbolj } \\
\text { finega žameta. }\end{array}$ \\
\hline
\end{tabular}

Razpredelnica 1: Sistem absolutnih in relativnih pridevniskib rab v anglě̌čini in slovenščini

Bistveni poudarek tu je, da je raba z notranjim standardom, ki jo poimenujemo tudi absolutna, ${ }^{2}$ in raba z zunanjim standardom, ki ji pravimo relativna, stvar rabe v konkretnem sobesedilu in ne inherentna lastnost pridevnika. Prav s tem je povezano tudi dejstvo, da so posamezne strategije pri rabi pridevnikov v različnih jezikih lahko različne. M. Kavalir (2014) tako kvalitativno ${ }^{3}$ pokaže, da je, primerjalno gledano, v slovenščini zelo produktivna raba notranjega standarda na srednji stopnji (kjer pomeni »kar«), v angleščini pa na visoki stopnji (kjer pomeni »zelo«).

Tu nastane vprašanje, ali imajo te razlike za posledico upoštevanja vreden prenos v medjezikovnem stiku. Tu gre lahko za transfer pri učenju angleščine (oziroma slovenščine) kot tujega jezika ali pa za interferenco pri prevajanju med jezikoma. ${ }^{4}$ Če združimo oboje, lahko pričakujemo, da bo učinek transferja najmočnejši, če pogledamo prevode prevajalcev, ki so še v procesu učenja tujega jezika.

Glede na to, da gre nedvomno za področje jezika, katerega obvladanje lahko v procesu usvajanja tujega jezika pričakujemo šele dokaj pozno, ne bi bilo presenetljivo, če bi se

2 Tu seveda ne mislimo na absolutne pridevnike v smislu Biberja idr. (2000: 526), ki pod tem pojmom razumejo pridevnike z inherentno presežnim pomenom, npr. unique, niti ne na absolutne presežnike v smislu I. Heim (1991), kjer za interpretacijo zadostujejo informacije, vsebovane v samostalniški zvezi; bliže smo zanimivi ideji Janežiča (1911: 48), ki je osnovno stopnjo imenoval nasebna in obliko nasebnik, kar bi lahko razumeli kot lastnost samo na sebi.

3 To področje je manj primerno za kvantitativno korpusno raziskavo, saj gre kljub leksikogramatičnemu refleksu, ki ga odločanje med absolutno in relativno rabo ima (v smislu statistično pomembnega vpliva na izbiro priponskega proti opisnemu stopnjevanju in pa različnih tonskih potekov, gl. Kavalir 2014, 2017), tu za tendence in ne enosmerno razmerje, zato ni mogoče strojno izluščiti npr. vseh absolutno rabljenih pridevnikov. Položaj zapletajo še drugi dejavniki, npr. nepopolna primerljivost korpusov, pomanjkanje korpusov govorjenega jezika, potreba po širšem sobesedilnem kontekstu in pomemben delež vsebin, prevedenih iz angleščine, v slovenskih korpusih.

4 Prevodni jezik, zaznamovan s prenosom struktur iz izhodiščnega jezika, je znan tudi kot prevajalščina (translationese; npr. Tirkkonen-Condit 2002). 
učinek transferja še vedno pojavljal tudi pri posameznikih, ki študirajo angleščino na stopnji C1 ali C2 na terciarni ravni. ${ }^{5}$ Lastna pedagoška praksa kaže, da v angleškem pisanju študentov prvega letnika na Oddelku za anglistiko in amerikanistiko Filozofske fakultete Univerze v Ljubljani pogosto najdemo primere, za katere se zdi, da jih kvalitativno zaznamuje prenos slovenskega absolutnega primernika. Nekaj zgledov (poudarila M. K.): ${ }^{6}$

- Going on an adventure is an excellent way to bring more versatility to our life. When we are on a trip or a vacation we can often find ourselves in situations we have never been in before. How we respond to it will definitely show us something new about our character since we cannot predict our reaction to that new environment. In some more extreme circumstances there is even a possibility of discovering new aspects of our mannerism.

- Besides, in these situations we really understand the true value of knowing ourselves and those around us. You get a line if you belong to the group of people who are more independent and self-sufficient or you form part of the opposite group that relies on others and also takes in consideration their point of view. Furthermore, you can draw a conclusion about what type of a person you are; more introvert or extrovert.

- Enormous amounts of money are being spent every year in order to rescue daring mountaineers from the Himalayas (and even our own modest mountains) and subsequently on their hospital treatment and rehabilitation. The tragedy lies in the fact that many of them return to their old ways as soon as possible-just let us be reminded of Tomaž Humar's story - and in case of a more serious injury, they represent an additional burden to society.

- $\quad$ Extreme sports are a fun and exciting way to spend your time, especially if you are bored with your usual activities. But they can also be very dangerous and can lead to accidents with serious consequences if you overrate yourself. Therefore, if you are thinking about taking up an extreme sport you better choose a more safe one and stick to the rules and instructions so that you can really enjoy yourself.

Za namene empirične preverbe hipoteze, da se pri medjezikovnem stiku angleščine in slovenščine pojavlja interferenca oziroma učinek negativnega transferja na področju absolutnih pridevniških rab, so bili v aprilu/maju 2009 študenti tretjega in četrtega letnika predbolonjskih programov, ki so poslušali seminar iz Prevajanja v angleščino oziroma Prevajanja v slovenščino na Oddelku za anglistiko in amerikanistiko Filozofske fakultete Univerze v Ljubljani pod vodstvom dr. Frančiške Lipovšek, ${ }^{7}$ zaprošeni za prostovoljno sodelovanje v raziskavi v okviru podiplomskega študija, ki se ukvarja »z nekaterimi

5 Predvidevamo sicer lahko, da bo še več primerov transfernih rab na nekoliko nižjih stopnjah, kot kaže npr. naslednji zgled v pisanju študenta Fakultete za gradbeništvo in geodezijo Univerze v Ljubljani (z dovoljenjem; poudarila M. K.): I am really interested in building ports or sea terminals, because I like everything connected with sea. And it would be really nice to design a larger sea Port like Port of Rotterdam or Port in Singapore.

6 Zadevni študenti so podali dovoljenje za vključitev odlomka v raziskovalno delo avtorice v okviru doktorskega študija. Vsi navedeni zgledi v članku so v celoti izvirni brez popravkov.

7 Pri izvedbi je bila ključna pomoč nosilke, za kar ji še enkrat iskrena hvala. 
pomenskimi in skladenjskimi razlikami med slovenščino in angleščino«, tako da niso bili vnaprej opozorjeni na področje v obravnavi. Študenti so dobili navodilo, da besedilo prevedejo »po svojih najboljših močeh, a brez uporabe elektronskih virov, « da bi se tako izognili vplivu nekaterih na spletu objavljenih prevodov.

Navodila in prevajalski primeri so bili ločeni za vsako od smeri prevajanja in izbrani glede na pričakovani transferni efekt, tako da so bili za prevajanje iz slovenščine v angleščino izbrani trije odlomki s skupaj štirimi absolutnimi primerniki, za prevajanje iz angleščine v slovenščino pa trije odlomki s skupaj štirimi absolutnimi presežniki. Skupno je v raziskavi sodelovalo 20 študentov, ${ }^{8}$ od tega 15 študentk in pet študentov, čeprav niso vsi prevedli vseh zgledov. Glede na relativno majhno število sodelujočih je raziskava tako predvsem kvalitativne narave; gledano na populacijo prevodov (do 80 prevodov primernikov in ravno tako do 80 prevodov presežnikov) je vseeno mogoče podati tudi kvantitativne tendence, vendar je treba upoštevati, da posamezni prevodi med seboj niso neodvisni. V nadaljevanju podajamo rezultate za vsak odlomek posebej.

Pri prevodu obstajajo tri možnosti: ali je uporabljena izhodiščna struktura (absolutni primernik oziroma presežnik), ali je uporabljena pridevniška zgradba, ki se izogne izhodiščni strukturi, ali pa je izvirna pridevniška zgradba sploh predrugačena. Kot izhaja iz hipoteze, predvidevamo, da med jezikoma obstajajo razlike v pogostnosti posameznih rab, ne pa v sami zmožnosti, da se absolutne rabe sploh pojavljajo. Za vsak posamezni prevod posameznega testiranca tako ne moremo nujno reči, da je ustrezen ali neustrezen, lahko pa iz celote vseh rešitev sklepamo, ali prihaja pri tej skupini anketirancev do zaznamovane pogostnosti posameznih rab. Za vse izbrane zglede obstaja možnost primerjave z javno objavljeno verzijo $\mathrm{v}$ drugem jeziku: zgledi $\mathrm{z}$ absolutnim primernikom vsi izhajajo iz dokumentov institucij Evropske unije in imajo uradno vsi status izvirnika, čeprav lahko sklepamo, da gre v praksi večinoma za prevajanje iz angleščine v slovenščino (pri čemer pa angleščina ni nujno prvotni izhodiščni jezik), metem ko so vsi zgledi z absolutnim presežnikom vzeti iz leposlovnih del, ki so prevedena v slovenščino.

\section{PRENOS ABSOLUTNEGA PRIMERNIKA IZ SLOVENŠČINE V ANGLEŠČINO}

\subsection{Mlajši odrasli}

Prva naloga je vzeta iz letnega poročila evropske ustanove za spremljanje drog (Evropski center za spremljanje drog in zasvojenosti z drogami 2007: 59), gre pa za naslednji graf:

8 Vsi študenti, vključeni v analizo, so materni govorci slovenščine. 
Prikaz 5: Trendi razširjenosti uživanja kokaina v zadnjem letu med mlajšimi odraslimi (v starosti od 15 do 34 let)

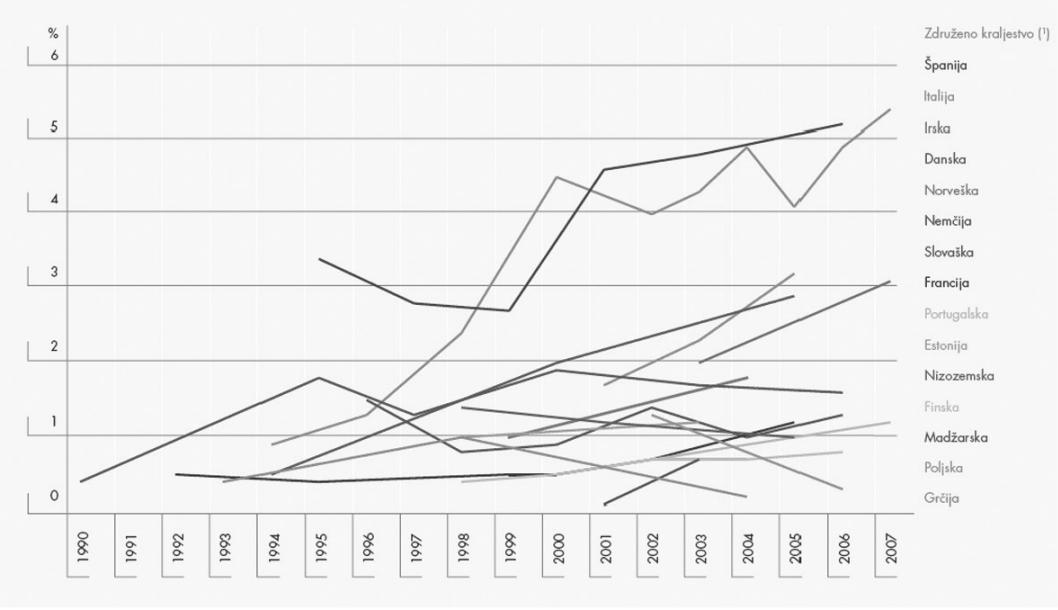

(1) Anglija in Wales. Viri:
Nacionalna poročila Reitox (2007), vzeta iz raziskav med prebivalstuom, poročil ali znanstvenih člankov.

Prikaz 1: Prevajanje iz slovenščine v angleščino, prva naloga

(Evropski center za spremljanje drog in zasvojenosti z drogami 2007: 59 2007: 59)

Angleška verzija poročila (European monitoring centre for drugs and drug addiction 2007: 59) isti graf podaja takole:

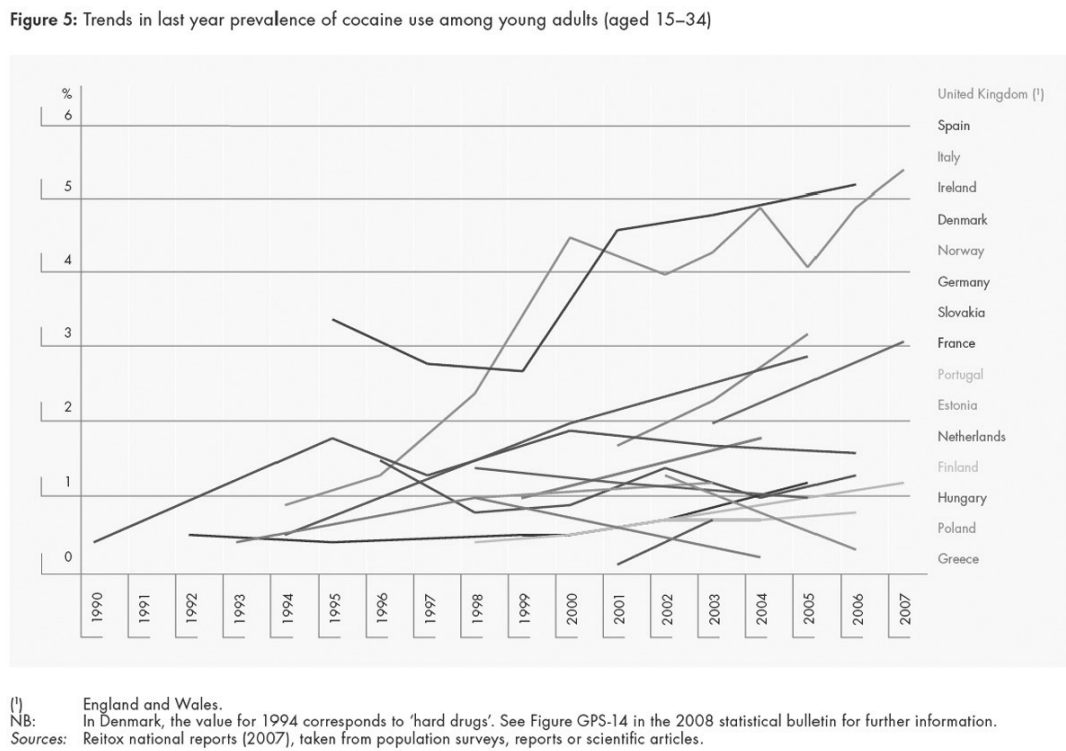

Prikaz 2: Prevajanje iz slovenščine $v$ angleščino, prva naloga

(European monitoring centre for drugs and drug addiction 2007: 59) 
Pridevniška zgradba, ki nas tu zanima, je termin mlajši odrasli oziroma njegova angleška ustreznica young adults; pregled literature kaže, da sta oba termina vsak v svojem jeziku normalno uveljavljena. V tem zgledu je mlajši klasifikator, ni pa povsem jasno, kakšen je v slovenščini njegov epitetski (opisni) izvor - ali gre tu za odrasle, ki so še kar mladi (tj. absolutna raba) ali za mlajše odrasle nasproti starejšim odraslim (tj. relativna raba). V vsakem primeru naloga testira občutljivost na rabo primernikov v angleščini. V razpredelnici 2 predstavljeni prevodi kažejo, da je ustrezni angleški izraz brez primernika uporabilo 15 študentov, štirje so tudi v angleščini uporabili primernik, en študent pa prevoda ni predlagal.

\begin{tabular}{|c|c|c|c|}
\hline Študent & Letnik & Prevod ANG 1 & Oblika ANG 1 \\
\hline 1 & 4 & $\begin{array}{l}\text { The spread of the trend in cocaine consumation among } \\
\text { young adults between in the last year (age 15-34) }\end{array}$ & 0 \\
\hline 2 & 4 & $\begin{array}{l}\text { The percentage of cocaine users among young adults } \\
\text { (aged 15-34) }\end{array}$ & 0 \\
\hline 3 & 3 & $\begin{array}{l}\text { Trends in cocaine use for last year among young adults } \\
\text { (aged 15-34) }\end{array}$ & 0 \\
\hline 4 & 3 & $\begin{array}{l}\text { A wide trend of taking cocaine in the last year among } \\
\text { young adults (ages from } 15 \text { to } 34 \text { ) }\end{array}$ & 0 \\
\hline 5 & 4 & $\begin{array}{l}\text { Range trends of cocain abuse in the last year among } \\
\text { younger adults (age between } 15 \text { to 34) }\end{array}$ & 1 \\
\hline 6 & 3 & $\begin{array}{l}\text { Trends in cocaine use among young adults (aged } 15-34 \text { ) } \\
\text { in the last year. }\end{array}$ & 0 \\
\hline 7 & 4 & $\begin{array}{l}\text { Trends in popularity of cocaine consumption among young } \\
\text { adults (between the ages of } 15 \text { and } 24 \text { ) in the last year. }\end{array}$ & 0 \\
\hline 8 & 4 & $\begin{array}{l}\text { Cocaine consumption among young adults (aged } 15 \text { to 34) } \\
\text { in the past year }\end{array}$ & 0 \\
\hline 9 & 3 & $\begin{array}{l}\text { Circulation of cocaine use in the last year among young } \\
\text { adults ( aged between } 15 \text { to 34) }\end{array}$ & 0 \\
\hline 10 & 3 & $\begin{array}{l}\text { The trends in taking cocaine in the last year among } \\
\text { younger adults (between the age of } 15 \text { and 34) }\end{array}$ & 1 \\
\hline 11 & 4 & I & / \\
\hline 12 & 4 & $\begin{array}{l}\text { The trends of enlarged use of cocaine among younger } \\
\text { adults (aged 15-34) in the last year }\end{array}$ & 1 \\
\hline 13 & 4 & $\begin{array}{l}\text { Trends of the dispersion of cocaine usage among young } \\
\text { adults (ages } 15 \text { to 34) in the last year }\end{array}$ & 0 \\
\hline 14 & 4 & $\begin{array}{l}\text { Wide circulation trends of consuming cocain in the last } \\
\text { year among young adults (age 15-34) }\end{array}$ & 0 \\
\hline 15 & 3 & $\begin{array}{l}\text { Trends in cocaine use in the last year among young adults } \\
\text { (ages } 15-34 \text { ) }\end{array}$ & 0 \\
\hline 16 & 4 & $\begin{array}{l}\text { Trends of cocaine spreading in the last year among young } \\
\text { adoults ( } 15 \text { to } 34 \text { years old) }\end{array}$ & 0 \\
\hline
\end{tabular}




\begin{tabular}{|c|c|l|c|}
\hline 17 & 4 & $\begin{array}{l}\text { Trends of ranges of cocaine abuse in the last year among } \\
\text { young adults (aged between 15 and 34) }\end{array}$ & 0 \\
\hline 18 & 3 & $\begin{array}{l}\text { The trends of cocaine consumption among the young } \\
\text { adults (aged between 15 and 34) in the last year }\end{array}$ & 0 \\
\hline 19 & 4 & $\begin{array}{l}\text { Range of cocaine usage among young adults (aged 15-34) } \\
\text { in the last year }\end{array}$ & 1 \\
\hline 20 & 4 & $\begin{array}{l}\text { The trend of cocaine consumption among younger adults } \\
\text { (aged 15 to 34) in the last year. }\end{array}$ & 0 \\
\hline
\end{tabular}

Razpredelnica 2: Prevajanje iz slovenščine $v$ angleščino, prva naloga ( $0=$ pridevniška zgradba brez primernika, 1 = pridevniška zgradba s primernikom, 2 = drugačna konstrukcija)

\subsection{Manjše število, daljši presledki}

Druga prevodna naloga se je glasila Litijev hipoklorit je priporočljiv v primerih, kjer gre za manjšse število analiz ali za analize, ki jih izvajamo v daljših presledkih (Direktiva Evropskega parlamenta in Sveta 96/73/ES 1996: 1) oziroma v angleški verziji Lithium hypochlorite is recommended in cases involving a small number of analyses or for analyses conducted at fairly lengthy intervals (Directive 96/73/EC of the European Parliament and of the Council 1996: 1). Poved je vključevala dva primera slovenskih absolutnih primernikov, in sicer v zvezah manjšs število in daljši presledki. V obeh primerih gre za jasno absolutno rabo, ki je dovolj pogosta, da bi lahko rekli, da se izraza uveljavljata kot kolokaciji. Angleška verzija ne vsebuje nobenega absolutnega primernika, vendar pa to ne pomeni, da ga nikakor ne bi smela - tako najdemo v korpusu BNC (British National Corpus) npr. However, the paper strength is only 74,000, of which a smaller number train regularly (poudarila M. K.). Kljub temu je povedno dejstvo, da je to eden zelo redkih absolutnih primerov in da vsebuje korpus $\mathrm{BNC}^{9}$ skupno samo 85 zadetkov za zvezo smaller number, medtem ko jih je v šestkrat večjem slovenskem korpusu FidaPLUS ${ }^{10}$ za manjšs število kar 37-krat več, 3.173.

\begin{tabular}{|c|c|l|c|}
\hline Študent & Letnik & \multicolumn{1}{|c|}{ Prevod ANG 2 } & Oblika ANG 2-1 \\
\hline 1 & 4 & $\begin{array}{l}\text { Lithia hipochlorite is recommendable in cases where there } \\
\text { is a smaller number of analyses or for analyses which are } \\
\text { carried out in longer intervals. }\end{array}$ & 1 \\
\hline 2 & 4 & $\begin{array}{l}\text { The use of lithium hypochlorite is recommended when } \\
\text { only a few analyses need to be made or when there is a } \\
\text { considerable break between individual analyses. }\end{array}$ & 2 \\
\hline 3 & 3 & $\begin{array}{l}\text { Lithium hypochlorite is recommended in cases involving a } \\
\text { small number of analysis or for analysis done over longer } \\
\text { intervals. }\end{array}$ & 0 \\
\hline
\end{tabular}

9 Iskanje operacionalizirano kot »smaller number«.

10 Iskanje operacionalizirano kot »\#1majhen\&\#2p?p*\#1število«. 


\begin{tabular}{|c|c|c|c|}
\hline Študent & Letnik & Prevod ANG 2 & Oblika ANG 2-1 \\
\hline 4 & 3 & $\begin{array}{l}\text { Lithium hipochlorite is advisable in cases where there are } \\
\text { minor numbers of analysis or for analyisis that are carried } \\
\text { out in longer intervals. }\end{array}$ & 1 \\
\hline 5 & 4 & $\begin{array}{l}\text { Lithium hypochlorite is recommended in cases, where we } \\
\text { are dealing with small number of analyses or for analyses, } \\
\text { which are carried out in longer intervals. }\end{array}$ & 0 \\
\hline 6 & 3 & $\begin{array}{l}\text { Lithium hypochlorite is suggested in cases of only a } \\
\text { few analyses or when analyses are carried out in longer } \\
\text { intervals. }\end{array}$ & 2 \\
\hline 7 & 4 & $\begin{array}{l}\text { Lithium hypochlorite is recommendable in cases where } \\
\text { there is a smaller number of analyses or where the } \\
\text { analyses are performed in long intervals. }\end{array}$ & 1 \\
\hline 8 & 4 & $\begin{array}{l}\text { It is advisable to employ lithium hypoclorite when dealing } \\
\text { with a smaller number of analyses or when conducting } \\
\text { analyses at longer intervals }\end{array}$ & 1 \\
\hline 9 & 3 & $\begin{array}{l}\text { Lithium hypochlorite is recommended in cases involving } \\
\text { a small number of analyses or for analyses conducted at } \\
\text { fairly lengthy intervals. }\end{array}$ & $0^{*}$ \\
\hline 10 & 3 & $\begin{array}{l}\text { Lithium hypochlorite is recommended in cases of a smaller } \\
\text { number of analyses or analyses that will be conducted at } \\
\text { longer intervals. }\end{array}$ & 1 \\
\hline 11 & 4 & I & I \\
\hline 12 & 4 & I & I \\
\hline 13 & 4 & $\begin{array}{l}\text { Lithium hypocloride is recommended for cases which } \\
\text { include only a small number of analyses and for analyses } \\
\text { which are made in larger intervals. }\end{array}$ & 0 \\
\hline 14 & 4 & $\begin{array}{l}\text { Lithium hypochlorite is advisable to be used in cases when } \\
\text { there are small numbers of analyses or when analyses are } \\
\text { carried out in larger intervals. }\end{array}$ & 0 \\
\hline 15 & 3 & $\begin{array}{l}\text { Lithium hypochlorite is advisable in cases where only a few } \\
\text { analyses are carried out or when the analyses are carried } \\
\text { out in longer intervals. }\end{array}$ & 2 \\
\hline 16 & 4 & $\begin{array}{l}\text { Lithium hypochlorite is recommended in cases with a } \\
\text { smaller number of analyses or for analyses performed in } \\
\text { longer periods. }\end{array}$ & 1 \\
\hline 17 & 4 & $\begin{array}{l}\text { Lithium hypochloride is recommended in cases where } \\
\text { smaller mount of analyses are carried out or for the } \\
\text { analyses that are performed in longer intervals. }\end{array}$ & 1 \\
\hline 18 & 3 & $\begin{array}{l}\text { Lithium hypochlorite is advisable in cases where there are } \\
\text { smaller numbers of analyses or there are analyses that are } \\
\text { performed in longer intervals. }\end{array}$ & 1 \\
\hline 19 & 4 & $\begin{array}{l}\text { The use of lithium hypochlorite is recomended in case } \\
\text { there is a smaller number of analysis or when analysis is } \\
\text { carried out in longer intervals. }\end{array}$ & 1 \\
\hline
\end{tabular}




\begin{tabular}{|c|c|l|c|}
\hline Študent & Letnik & \multicolumn{1}{|c|}{ Prevod ANG 2 } & Oblika ANG 2-1 \\
\hline 20 & 4 & $\begin{array}{l}\text { Lithium hypochlorite is recommended in cases, where } \\
\text { there is a smaller amount of analyses or for analysis which } \\
\text { are done in larger intervals. }\end{array}$ & 1 \\
\hline
\end{tabular}

Razpredelnica 3: Prevajanje iz slovenščine v angleščino, druga naloga, manjše število

$(0=$ pridevniska zgradba brez primernika, $1=$ pridevnišk a zgradba s primernikom, 2 = drugačna konstrukcija; * = identično uradni angleški verziji)

\begin{tabular}{|c|c|c|c|}
\hline Študent & Letnik & Prevod ANG 2 & Oblika ANG 2-2 \\
\hline 1 & 4 & $\begin{array}{l}\text { Lithia hipochlorite is recommendable in cases where there } \\
\text { is a smaller number of analyses or for analyses which are } \\
\text { carried out in longer intervals. }\end{array}$ & 1 \\
\hline 2 & 4 & $\begin{array}{l}\text { The use of lithium hypochlorite is recommended when } \\
\text { only a few analyses need to be made or when there is a } \\
\text { considerable break between individual analyses. }\end{array}$ & 2 \\
\hline 3 & 3 & $\begin{array}{l}\text { Lithium hypochlorite is recommended in cases involving a } \\
\text { small number of analysis or for analysis done over longer } \\
\text { intervals. }\end{array}$ & 1 \\
\hline 4 & 3 & $\begin{array}{l}\text { Lithium hipochlorite is advisable in cases where there are } \\
\text { minor numbers of analysis or for analyisis that are carried } \\
\text { out in longer intervals. }\end{array}$ & 1 \\
\hline 5 & 4 & $\begin{array}{l}\text { Lithium hypochlorite is recommended in cases, where we } \\
\text { are dealing with small number of analyses or for analyses, } \\
\text { which are carried out in longer intervals. }\end{array}$ & 1 \\
\hline 6 & 3 & $\begin{array}{l}\text { Lithium hypochlorite is suggested in cases of only a } \\
\text { few analyses or when analyses are carried out in longer } \\
\text { intervals. }\end{array}$ & 1 \\
\hline 7 & 4 & $\begin{array}{l}\text { Lithium hypochlorite is recommendable in cases where } \\
\text { there is a smaller number of analyses or where the } \\
\text { analyses are performed in long intervals. }\end{array}$ & 0 \\
\hline 8 & 4 & $\begin{array}{l}\text { It is advisable to employ lithium hypoclorite when dealing } \\
\text { with a smaller number of analyses or when conducting } \\
\text { analyses at longer intervals }\end{array}$ & 1 \\
\hline 9 & 3 & $\begin{array}{l}\text { Lithium hypochlorite is recommended in cases involving } \\
\text { a small number of analyses or for analyses conducted at } \\
\text { fairly lengthy intervals. }\end{array}$ & $0^{*}$ \\
\hline 10 & 3 & $\begin{array}{l}\text { Lithium hypochlorite is recommended in cases of a } \\
\text { smaller number of analyses or analyses that will be } \\
\text { conducted at longer intervals. }\end{array}$ & 1 \\
\hline 11 & 4 & I & / \\
\hline 12 & 4 & / & l \\
\hline 13 & 4 & $\begin{array}{l}\text { Lithium hypocloride is recommended for cases which } \\
\text { include only a small number of analyses and for analyses } \\
\text { which are made in larger intervals. }\end{array}$ & 1 \\
\hline
\end{tabular}




\begin{tabular}{|c|c|l|c|}
\hline Študent & Letnik & \multicolumn{1}{|c|}{ Prevod ANG 2 } & Oblika ANG 2-2 \\
\hline 14 & 4 & $\begin{array}{l}\text { Lithium hypochlorite is advisable to be used in cases } \\
\text { when there are small numbers of analyses or when } \\
\text { analyses are carried out in larger intervals. }\end{array}$ & 1 \\
\hline 15 & 3 & $\begin{array}{l}\text { Lithium hypochlorite is advisable in cases where only } \\
\text { a few analyses are carried out or when the analyses are } \\
\text { carried out in longer intervals. }\end{array}$ & 1 \\
\hline 16 & 4 & $\begin{array}{l}\text { Lithium hypochlorite is recommended in cases with a } \\
\text { smaller number of analyses or for analyses performed in } \\
\text { longer periods. }\end{array}$ & 1 \\
\hline 17 & 4 & $\begin{array}{l}\text { Lithium hypochloride is recommended in cases where } \\
\text { smaller mount of analyses are carried out or for the } \\
\text { analyses that are performed in longer intervals. }\end{array}$ & 1 \\
\hline 19 & 3 & $\begin{array}{l}\text { Lithium hypochlorite is advisable in cases where there are } \\
\text { smaller numbers of analyses or there are analyses that are } \\
\text { performed in longer intervals. }\end{array}$ & 1 \\
\hline 20 & 4 & $\begin{array}{l}\text { The use of lithium hypochlorite is recomended in case } \\
\text { there is a smaller number of analysis or when analysis is } \\
\text { carried out in longer intervals. }\end{array}$ & $\begin{array}{l}\text { Lithium hypochlorite is recommended in cases, where } \\
\text { there is a smaller amount of analyses or for analysis which } \\
\text { are done in larger intervals. }\end{array}$ \\
\hline
\end{tabular}

Razpredelnica 4: Prevajanje iz slovenščine v angleščino, druga naloga, daljši presledki $(0=$ pridevniska zgradba brez primernika, 1 = pridevnišk a zgradba s primernikom, 2 = drugačna konstrukcija; * = identično uradni angleski verziji)

Razpredelnici 3 in 4 kažeta, da je manjše število s primernikom prevedlo 10 študentov, s pridevniško zgradbo brez primernika pet študentov, trije študenti so zgradbo povsem spremenili. Pri daljših presledkih je bilo prevodov s primernikom še več, kar 15, dva študenta sta uporabila pridevniško zgradbo brez pridevnika, eden pa drugačno konstrukcijo. Dva študenta prevoda te naloge nista podala, omeniti pa je treba tudi dejstvo, da je eden od študentov za ta zgled poiskal in podal uradno angleško različico.

\subsection{Zahtevnejše jedi}

Tretja naloga prevajanja $\mathrm{v}$ angleščino izvira iz še enega dokumenta EU, in sicer se glasi [N] amizne oljke so naravni in zdravi proizvod, ki se jih lahko je kot prigrizek ali v zahtevnejših jedeh v slovenščini (Uredba Komisije (ES) št. 497/2003 2003: 4) in [T]able olives are a natural and healthy product, which can be eaten as snacks or in complex dishes $\mathrm{V}$ angleščini (Commission Regulation (EC) No 497/2003 2003: 4). Zanima nas absolutni primernik zahtevnejše jedi, ki ga lahko interpretiramo kot povsem prosto zvezo in rezultat produktivnosti absolutne rabe v slovenščini. ${ }^{11}$

11 Na tem mestu se ne spuščamo $\mathrm{v}$ analizo nekaterih problematičnih značilnosti slovenskega navedka, kot sta določna oblika pridevnikov in prisotnost zaimka jih. 


\begin{tabular}{|c|c|c|c|}
\hline Študent & Letnik & Prevod ANG 3 & Oblika ANG 3 \\
\hline 1 & 4 & $\begin{array}{l}\text { Table olives are a natural and healthy product, which can be } \\
\text { eaten as a snack or in more exacting dishes. }\end{array}$ & 1 \\
\hline 2 & 4 & $\begin{array}{l}\text { Table olives are a natural and healthy product, which can be } \\
\text { enjoyed not only as a simple snack but also in sophisticated } \\
\text { dishes. }\end{array}$ & 0 \\
\hline 3 & 3 & $\begin{array}{l}\text { Olive is a completely natural and healthy product which can } \\
\text { be served as a snack or an ingredient in a more complex dish. }\end{array}$ & 1 \\
\hline 4 & 3 & $\begin{array}{l}\text { Table olives are natural and healthy products that can be } \\
\text { eaten as a snack or in more pretentious meals. }\end{array}$ & 1 \\
\hline 5 & 4 & $\begin{array}{l}\text { Table olives are natural and healthy product, which can be } \\
\text { eaten as a snack or in more elaborate dishes. }\end{array}$ & 1 \\
\hline 6 & 3 & $\begin{array}{l}\text { Edible olives are a natural and healthy product, served either } \\
\text { as a snack or used in prepared dishes. }\end{array}$ & 2 \\
\hline 7 & 4 & $\begin{array}{l}\text { Tabletop olives are a natural and healthy product, and can } \\
\text { be consumed as a snack or as an ingredient of more complex } \\
\text { dishes. }\end{array}$ & 1 \\
\hline 8 & 4 & $\begin{array}{l}\text { Table olives are natural and healthy products, which can be } \\
\text { consumed as snacks or as ingredients of more complex dishes. }\end{array}$ & 1 \\
\hline 9 & 3 & $\begin{array}{l}\text { Table olives are a natural and healthy product, which can be } \\
\text { eaten as snacks or in complex dishes. }\end{array}$ & $0^{*}$ \\
\hline 10 & 3 & $\begin{array}{l}\text { Table olives are a healthy and natural product that can be } \\
\text { served as a snack or used in other more challenging dishes. }\end{array}$ & 1 \\
\hline 11 & 4 & 1 & 1 \\
\hline 12 & 4 & $\begin{array}{l}\text { Table olives are a natural and healthy product that can be } \\
\text { eaten as a snack or in more demanding dishes. }\end{array}$ & 1 \\
\hline 13 & 4 & $\begin{array}{l}\text { Table olives are a natural and a healthy product, which can be } \\
\text { eaten as a side-dish or as an ingredient of more demanding } \\
\text { dishes }\end{array}$ & 1 \\
\hline 14 & 4 & $\begin{array}{l}\text { Table olives are a natural and healthy product that could be } \\
\text { eaten as a snack or be part of exacting dishes. }\end{array}$ & 0 \\
\hline 15 & 3 & I & I \\
\hline 16 & 4 & $\begin{array}{l}\text { Table olive trees are a natural and healthy product, which can } \\
\text { be eaten as a snack or in a more complicated dishes. }\end{array}$ & 1 \\
\hline 17 & 4 & $\begin{array}{l}\text { Table olives are a natural and healthy product that can be } \\
\text { eaten as a short meal or within more exacting dishes. }\end{array}$ & 1 \\
\hline 18 & 3 & $\begin{array}{l}\text { Table olives are natural and healthy products that can be } \\
\text { eaten as a collation or in more pretentious dishes. }\end{array}$ & 1 \\
\hline 19 & 4 & $\begin{array}{l}\text { The table olive tree is a natural and healthy product, which can } \\
\text { be consumed as a snack or used as an ingredient in meals. }\end{array}$ & 2 \\
\hline 20 & 4 & $\begin{array}{l}\text { Olives are a natural and healthy product, which can be eaten } \\
\text { as a snack or as part of (in) more complex dishes. }\end{array}$ & 1 \\
\hline
\end{tabular}

Razpredelnica 5: Prevajanje iz slovenščine $v$ angleščino, tretja naloga

( 0 = pridevniska zgradba brez primernika, 1 = pridevnišk a zgradba s primernikom, 2 = drugačna konstrukcija; * = identično uradni angleski verziji) 
Iz rezultatov, zabeleženih $\mathrm{v}$ razpredelnici 5, lahko razberemo, da je 13 študentov prevedlo zahtevnejše jedi s primernikom, trije študenti so uporabili pridevniško zgradbo brez primernika, dva sta $\mathrm{v}$ tem delu popolnoma spremenila strukturo, dva pa prevoda nista podala. ${ }^{12}$ Študent št. 9 je tudi tu poiskal in predlagal uradno angleško različico.

\subsection{Povzetek rezultatov}

\begin{tabular}{|c|c|c|c|c|c|}
\hline Naloga & Zgled & $\begin{array}{c}\text { Število prevodov } \\
\text { s pridevniško } \\
\text { zgradbo brez } \\
\text { primernika }\end{array}$ & $\begin{array}{c}\text { Število prevodov } \\
\text { s pridevniško } \\
\text { zgradbo s } \\
\text { primernikom }\end{array}$ & $\begin{array}{c}\text { Število } \\
\text { prevodov z } \\
\text { drugačno } \\
\text { konstrukcijo }\end{array}$ & Skupaj \\
\hline 1 & mlajši odrasli & 15 & 4 & 0 & 19 \\
\hline $2-1$ & manjše število & $4+1$ & 10 & 3 & 18 \\
\hline $2-2$ & daljši presledki & $1+1$ & 15 & 1 & 18 \\
\hline 3 & zahtevnejšejedi & $2+1$ & 13 & 2 & 18 \\
\hline Skupaj & & $22+3$ & 42 & 6 & 73 \\
\hline
\end{tabular}

Razpredelnica 6: Prevajanje iz slovenšcine v angleščino, povzetek rezultatov

Skupni rezultati, zbrani v razpredelnici 6, kažejo, da so študenti tretjega in četrtega letnika anglistike uspešno prepoznali razliko med slovenščino in angleščino v rabi termina mlajši odrasli, medtem ko so pri ostalih treh zgledih tudi v angleščini pokazali zelo močno nagnjenje $\mathrm{k}$ rabi absolutnega primernika, saj je v tem delu takšnih kar 38 od 54 prevodov. Če pogledamo primere, kot si sledijo po stopnji ustaljenosti od termina prek močnejše in šibkejše kolokacije do proste zveze, se zdi, da je razlog za prevladujočo neprimerniško rabo v primeru mlajši odrasli $\mathrm{v}$ tem, da so študenti to zvezo prepoznali kot leksem in ji kot celoti iskali angleško ustreznico, medtem ko je v drugih primerih močnejši slovnični vidik s sistemsko absolutno rabo, ki pa ni bila prepoznana. To kaže na močan učinek transferja in na dejstvo, da leksikogramatična razlika med slovenščino in angleščino na področju absolutnega primernika tudi na tej stopnji učenja angleščine še ni uzaveščena.

12 Točneje, student št. 15 je podal prevod, a je iz neznanih razlogov spremenil izhodiščno besedilo, tako da se je glasilo Edible olives are a natural and healthy product, which can be served as a snack or used in other dishes. 


\section{PRENOS ABSOLUTNEGA PRESEŽNIKA IZ ANGLEŠČINE V SLOVENŠČINO}

\subsection{A most amazing female}

Prva prevodna naloga pri prevajanju iz angleščine v slovenščino izvira iz ljubezenskega romana Amande Quick. Izvirnik se glasi Sebastian glanced at her with an expression of cool admiration. 'You've been very observant. But I cannot say I'm surprised. You are a most amazing female' (Quick 1993: 69), slovensko besedilo (v prevodu Jasne Kešpret) pa Sebastian jo je pogledal z občudovanjem. 'Zelo dobro opazujě̌. Vendar ne morem reči, da sem presenečen. Ti si najbolj presenetljiva ženska' (Quick 2002: 76). Zanima nas absolutni presežnik a most amazing (female). Kot je razvidno, je tudi v slovenščini uporabljen presežnik, vendar pa bi bilo mogoče trditi, da bi ga običajni naslovnik v nasprotju $\mathrm{z}$ absolutno interpretacijo $\mathrm{v}$ angleščini razumel kot relativno rabo in gre $\mathrm{v}$ tem smislu za neustrezen pomenski premik.

\begin{tabular}{|c|c|c|c|}
\hline Študent & Letnik & Prevod SLO 1 & Oblika SLO 1 \\
\hline 1 & 4 & $\begin{array}{l}\text { Sebastian jo je oplazil s pogledom hladnega občudovanja: } \\
\text { "Zelo dobro opazuješ, vendar ne morem reči, da sem } \\
\text { presenečen, saj si osupljiva ženska." }\end{array}$ & 0 \\
\hline 2 & 4 & $\begin{array}{l}\text { Sebastian jo je ošinil z izrazom čistega občudovanja na obrazu. } \\
\text { "Dobro opazuješ. Ne morem pa reči, da si me presenetila. } \\
\text { Neverjetna ženska si." }\end{array}$ & 0 \\
\hline 3 & 3 & $\begin{array}{l}\text { Sebastian jo je pogledal z občudovanjem v očeh. »Zelo dobro } \\
\text { opazuješ. Vendar moram dodati, da me to ne preseneča. Si } \\
\text { zares izjemna ženska.» }\end{array}$ & 0 \\
\hline 4 & 3 & $\begin{array}{l}\text { Sebastian jo je bežno pogledal s hladnim občudovanjem. "Bila } \\
\text { si zelo pazljiva. Ampak ne morem reči, da sem presenečen. Si } \\
\text { najbolj čudovita ženska." }\end{array}$ & 1 \\
\hline 5 & 4 & $\begin{array}{l}\text { Sebastian jo je ošvignil s pogledom, ki je izžareval } \\
\text { občudovanje. Zelo dobro opazuješ, ampak ne bom rekel, da } \\
\text { sem presenečen. Si zelo posebna ženska. }\end{array}$ & 0 \\
\hline 6 & 3 & $\begin{array}{l}\text { Sebastian jo je pogledal z izrazom hladnega občudovanja. } \\
\text { Si pa zelo pozorna. A vendar ne morem trditi, da sem } \\
\text { presenečen. Si naravnost čudovita ženska. }\end{array}$ & 0 \\
\hline 7 & 4 & $\begin{array}{l}\text { Sebastian je je pogledal z izrazom zadržanega občudovanja. } \\
\text { "Dobro opazuješ. Ne morem reči da nisem presenečen, saj si } \\
\text { nadvse neverjetna ženska!' }\end{array}$ & 0 \\
\hline 8 & 4 & $\begin{array}{l}\text { Sebastian jo je oplazil s pogledom, ki je izražal hladno } \\
\text { občudovanje. "Dobro opazuješ. A ne bi mogel reči, da sem } \\
\text { presenečen. Si nadvse izredna ženska." }\end{array}$ & 0 \\
\hline 9 & 3 & $\begin{array}{l}\text { Sebastian jo je bežno pogledal z izrazom predrznega } \\
\text { občudovanja. "Zelo dobro opazuješ. Ne morem reči, da me to } \\
\text { presneča. Si najbolj čudovita ženska." }\end{array}$ & 1 \\
\hline 10 & 3 & / & / \\
\hline
\end{tabular}




\begin{tabular}{|c|c|c|c|}
\hline Študent & Letnik & Prevod SLO 1 & Oblika SLO 1 \\
\hline 11 & 4 & $\begin{array}{l}\text { Sebastijan jo je gledal s čistim občudovanjem. »Zelo si pazljiva. } \\
\text { Ampak ne morem reči, da sem presenečen. Si zelo osupljiva } \\
\text { ženska.« }\end{array}$ & 0 \\
\hline 12 & 4 & $\begin{array}{l}\text { Sebastjan jo je pogledal z izrazom občudovanja. "Do zdaj si } \\
\text { veliko opazila. Ne morem pa trditi da sem presenečen. Ti si } \\
\text { izredno osupljiva ženska." }\end{array}$ & 0 \\
\hline 13 & 4 & $\begin{array}{l}\text { Sebastian jo je ošvrknil z hladnim odobravanjem. "Si pa zelo } \\
\text { dovzetna za dogajanje okoli sebe, a to me ne preseneča. } \\
\text { Osupljivo dekle si. }\end{array}$ & 0 \\
\hline 14 & 4 & $\begin{array}{l}\text { Sebastian jo je bežno pogledal z izrazom hladnega } \\
\text { občudovanja. "Bila si zelo pazljiva, vendar ne morem reči, da } \\
\text { sem presenečen. Neverjetna ženska si." }\end{array}$ & 0 \\
\hline 15 & 3 & $\begin{array}{l}\text { Sebastian jo je bežno pogledal z izrazom polnega } \\
\text { občudovanja. Zelo pozorna si. Ampak ne morem trditi, da } \\
\text { nisem presenečen. Zares čudovita ženska si. }\end{array}$ & 0 \\
\hline 16 & 4 & $\begin{array}{l}\text { Sebastian jo je pogledal z izrazom polnim občudovanja. "Bila } \\
\text { si zelo pozorna. A ne morem reči, da sem presenečen. Si zelo } \\
\text { osupljiva ženska." }\end{array}$ & 0 \\
\hline 17 & 4 & $\begin{array}{l}\text { Sebastjan jo je bežno pogledal z izrazom mirnega } \\
\text { občudovanja na obrazu. "Bila si zelo pazljiva. Ampak nisem } \\
\text { presenečen, saj si najbolj čudovita ženska." }\end{array}$ & 1 \\
\hline 18 & 3 & $\begin{array}{l}\text { Sebastian jo je bežno pogledal z izrazom hladnega } \\
\text { občudovanja: »Zelo ste opazovali. Vendar me to ne preseneča. } \\
\text { Ste namreč najbolj osupljiva ženska. }\end{array}$ & 1 \\
\hline 19 & 4 & $\begin{array}{l}\text { Sebastjan jo je oplazil s pogledom polnim občudovanja. } \\
\text { "Dobro si opazovala, ampak ne morem reči da sem } \\
\text { presenečen, saj si zelo čudovita ženska." }\end{array}$ & 0 \\
\hline 20 & 4 & $\begin{array}{l}\text { Sebastian jo je pogledal z izrazom hladnega občudovanja. “Ti } \\
\text { zelo dobro opazuješ. Pa saj me to niti ne preseneča. Si zelo } \\
\text { čudovita/ osupljiva ženska” }\end{array}$ & 0 \\
\hline
\end{tabular}

Razpredelnica 7: Prevajanje iz angleščine $v$ slovenščino, prva naloga ( $0=$ pridevniška zgradba brez presežnika, 1 = pridevniška zgradba s presežnikom, 2 =drugačna konstrukcija)

Kot kažejo rezultati v razpredelnici 7, je 15 študentov v prevodu izraza a most amazing female uporabilo pridevniško zgradbo brez presežnika, štirje so uporabili zgradbo s presežnikom, eden pa prevoda ni podal.

\subsection{The strangest thing}

Druga prevodna naloga je vzeta iz kriminalnega romana Jamesa Pattersona. Izvirnik se glasi I saw a blond man, and he did the strangest thing: He bowed in our direction. I couldn't believe what he'd just done. Taken a bow? (Patterson 2006: 32), slovensko besedilo (v prevodu Mihe Avanza) pa Zagledal sem plavolasca, ki je naredil nekaj zelo 
čudnega: priklonil se nama je. Nisem mogel verjeti svojim očem. Priklon? (Patterson 2009: 35).

Zanima nas zveza the strangest thing. Tu gre za značilno angleško absolutno presežniško rabo, ki se je razvila v kolokacijo. Korpus BNC vsebuje devet primerov te zveze, ${ }^{13}$ medtem ko je v šestkrat večjem korpusu FidaPLUS sedem primerov zveze najbolj čudna stvar, ${ }^{14}$ od katerih so vsaj trije neposredno navezani na angleški vir (npr. Nevrofiziolog John Harrison v knjigi Synaesthesia, the Strangest Thing - Sinestezija, najbolj čudna stvar ( Oxford University Press) raziskuje vzrok, zaradi katerega pride do tega mešanja čutov; poudarila M. K.), in nobenega primera najčudnejše stvari ${ }^{15}$. Sklepamo lahko, da slovenski absolutni presežnik v podobnem govornem položaju ni izključen, ni pa tako pogost kot v angleščini.

\begin{tabular}{|c|c|c|c|}
\hline Študent & Letnik & Prevod SLO 2 & Oblika SLO 2 \\
\hline 1 & 4 & $\begin{array}{l}\text { Videl(a) sem blondinca in napravil je nenavadno stvar: Priklonil se } \\
\text { je v našo smer. Ne morem verjeti, da je to napravil. Prikloniti se? }\end{array}$ & 0 \\
\hline 2 & 4 & $\begin{array}{l}\text { Videl(a) sem moškega s svetlimi lasmi. Naredil je nekaj zares } \\
\text { čudnega: priklonil se je v našo smer. Nisem mogel /-la verjeti, } \\
\text { kaj je naredil. Se je res priklonil? (Priklonil se je? (če gre za } \\
\text { odziv sogovorca)) }\end{array}$ & 0 \\
\hline 3 & 3 & $\begin{array}{l}\text { Videl sem moškega s svetlimi lasmi, ki je naredil nekaj zelo } \\
\text { nenavadnega: priklonil se nam je. Nisem mogel verjeti očem, } \\
\text { da se nam je priklonil. }\end{array}$ & 0 \\
\hline 4 & 3 & $\begin{array}{l}\text { Videl sem svetlolasega človeka, ki je naredil najbolj čudno } \\
\text { stvar: Priklonil se je v našo smer. Nisem mogel verjeti, kaj je } \\
\text { pravkar naredil. Prikloniti se? }\end{array}$ & 1 \\
\hline 5 & 4 & $\begin{array}{l}\text { Videl sem svetlolasega moškega, ki je naredil zelo čudno stvar: } \\
\text { priklonil se je v našo smer. Nisem mogel verjeti. Prikloniti se? }\end{array}$ & 0 \\
\hline 6 & 3 & $\begin{array}{l}\text { Videla sem svetlolasega moža, ki je naredil najbolj nenavadno } \\
\text { stvar: poklonil se nam je. Nisem mogla verjeti kaj je storil. } \\
\text { Poklon? }\end{array}$ & 1 \\
\hline 7 & 4 & $\begin{array}{l}\text { Videl sem svetlolasega moža, ki je naredil res nenavadno } \\
\text { gesto: Priklonil se je v našo smer. Nisem mogel verjeti kaj je } \\
\text { pravkar storil. Se priklonil? }\end{array}$ & 0 \\
\hline 8 & 4 & $\begin{array}{l}\text { Videl sem svetlolasega moškega, ki je naredil nekaj zelo } \\
\text { nenavadnega: priklonil se nam je. Nisem mogel verjeti, da je to } \\
\text { pravkar storil. Se priklonil? }\end{array}$ & 0 \\
\hline 9 & 3 & $\begin{array}{l}\text { Videla sem svetlolasega moškega, ki je naredil nekaj najbolj } \\
\text { nenavadnega. Poklonil se je v našo smer. Nisem mogla verjeti } \\
\text { temu, kaj je naredil. Poklon? }\end{array}$ & 1 \\
\hline 10 & 3 & I & I \\
\hline
\end{tabular}

13 Iskanje operacionalizirano kot »strangest thing«.

14 Iskanje operacionalizirano kot »najbolj_\#1čuden_\#1stvar«.

15 Iskanje operacionalizirano kot »\#1čuden\&\#2p?s*_\#1stvar«. 


\begin{tabular}{|c|c|c|c|}
\hline Študent & Letnik & Prevod SLO 2 & Oblika SLO 2 \\
\hline 11 & 4 & $\begin{array}{l}\text { Videl sem moškega svetlih las, ki je naredil nekaj zelo } \\
\text { nenavadnega: Priklonil se je proti nam. Nisem mogel verjeti } \\
\text { kar je pravkar storil. Priklonil se je? }\end{array}$ & 0 \\
\hline 12 & 4 & $\begin{array}{l}\text { Videl sem svetlolasega moškega in naredil je nekaj zelo } \\
\text { čudnega. Priklonil se je v našo smer. Nisem mogel verjeti kaj je } \\
\text { pravkar naredil. Se je klanjal? }\end{array}$ & 0 \\
\hline 13 & 4 & $\begin{array}{l}\text { Videla sem nekega blondinca, čigar početje me je presenetilo, } \\
\text { saj se nam je priklonil. Nisem mogla verjeti, da je storil to. Nam } \\
\text { namenil priklon? }\end{array}$ & 0 \\
\hline 14 & 4 & $\begin{array}{l}\text { Videl sem plavolasega moškega, ki je naredil nekaj čudnega. } \\
\text { Obrnjen proti nam se je priklonil! Nisem mogel verjeti, kaj je } \\
\text { ravnokar storil. Priklonil? }\end{array}$ & 0 \\
\hline 15 & 3 & $\begin{array}{l}\text { Videla sem plavolasega moža, ki je naredil zared čudno stvar: } \\
\text { poklonil se nam je naravnost v našo smer. Nisem mogla verjeti } \\
\text { kaj je pravkar storil. Poklonil se je? }\end{array}$ & 0 \\
\hline 16 & 4 & $\begin{array}{l}\text { Videl sem blond moškega, ki je naredil nekaj zelo čudnega. } \\
\text { Priklonil se je v našo smer. Nisem mogel verjeti kaj je pravkar } \\
\text { storil. Priklonil se je? }\end{array}$ & 0 \\
\hline 17 & 4 & $\begin{array}{l}\text { Videla sem plavolasega moškega, ki je naredil nekaj zelo } \\
\text { čudnega: Priklonil se je v našo smer. Nisem mogla verjeti, kaj je } \\
\text { naredil. Priklonil se je? }\end{array}$ & 0 \\
\hline 18 & 3 & $\begin{array}{l}\text { Videla sem svetlolasega moškega, ki je potem storil nekaj } \\
\text { nepričakovanega: priklonil se je v našo smer. Nisem mogla } \\
\text { verjeti, kaj je ravnokar storil. Da se je priklonil? }\end{array}$ & 0 \\
\hline 19 & 4 & $\begin{array}{l}\text { Videl sem svetlolasega moškega, ki je naredil nekaj zelo } \\
\text { čudnega: Priklonil se nam je. Nisem mogel verjeti kaj je naredil. } \\
\text { Priklonil se je? }\end{array}$ & 0 \\
\hline 20 & 4 & $\begin{array}{l}\text { Videla sem svetlolasega človeka, ki je naredil zelo čudno stvar: } \\
\text { Priklonil se nam je. Nisem mogla verjet, da je to res naredil. } \\
\text { Priklonil se? }\end{array}$ & 0 \\
\hline
\end{tabular}

Razpredelnica 8: Prevajanje iz angleščine v slovenščino, druga naloga ( 0 = pridevniška zgradba brez presežnika, 1 = pridevniška zgradba s presežnikom, 2 = drugačna konstrukcija)

Iz razpredelnice 8 lahko razberemo, da je 16 študentov pri prevodu izraza the strangest thing uporabilo pridevniško zgradbo brez presežnika, trije so uporabili zgradbo s presežnikom, eden pa predloga prevoda ni podal.

\subsection{The most gorgeous green eyes, the cutest little plaid bow}

Zadnja prevodna naloga prihaja iz istega vira kot predhodna, tj. kriminalnega romana Jamesa Pattersona. Angleški izvirnik se glasi She had the most gorgeous green eyes, full red lips, and the cutest little plaid bow planted in her hair. Sullivan had decided one thing about her right away - Marianne was a little cock tease, and that was all right with him. 
He liked to play games too (Patterson 2006: 14), slovensko besedilo (v prevodu Mihe Avanza) pa Imela je čudovite zelene oči, polne rdeče ustnice in srčkano karirasto pentljo v laseh. Sullivanu je nekaj takoj postalo jasno - mala je zapeljivka in nič ni imel proti. Tudi sam se je rad poigraval (Patterson 2009: 20). V odlomku sta prisotna dva angleška absolutna presežnika, the most gorgeous (green eyes) in the cutest (little plaid bow).

\begin{tabular}{|c|c|c|c|}
\hline Študent & Letnik & Prevod SLO 3 & Oblika SLO 3-1 \\
\hline 1 & 4 & $\begin{array}{l}\text { Imela je krasne zelene oči, polne rdeče usnice in sladko } \\
\text { karirasto pentljo v laseh. Sullivan se je takoj zaključil nekaj } \\
\text { o njej - Marianne je bila navihana nagajivka, in to mu je } \\
\text { bilo všeč. Tudi sam se je rad igral igrice. }\end{array}$ & 0 \\
\hline 2 & 4 & $\begin{array}{l}\text { Imela je prekrasne zelene oči, polne rdeče ustnice in } \\
\text { srčkano karirasto pentljico v laseh. Sullivanu je nekaj v hipu } \\
\text { postalo jasno - Marianne je spogledljivka, in ni ga motilo. } \\
\text { Tudi on se je rad igral. }\end{array}$ & 0 \\
\hline 3 & 3 & $\begin{array}{l}\text { Imela je prečudovite zelene oči, polne rdeče ustnice in } \\
\text { nadvse prisrčno pentljo v laseh. Sullivan je takoj spoznal } \\
\text { nekaj o njej - Marianne je bila dražljivka in njemu je to } \\
\text { ustrezalo. Tudi on je se je rad igral. }\end{array}$ & 0 \\
\hline 4 & 3 & $\begin{array}{l}\text { Imela je najbolj čudovite zelene oči, polne rdeče ustnice in } \\
\text { prisrčno majhno karirasto pentljo v laseh. Sullivan se je eno } \\
\text { stvar glede nje takoj odločil - Marianne je bila zapeljivka in } \\
\text { to ga ni motilo. Tudi on se je rad igral. }\end{array}$ & 1 \\
\hline 5 & 4 & $\begin{array}{l}\text { Imela je najbolj čudovite zelene oči, polne rdeče ustnice, in } \\
\text { pa zelo srčkano majhno karirasto pentljo v laseh. Sullivan } \\
\text { se je v trenutku odločil - Marianne je bila spogledljivka in } \\
\text { to ga ni motilo. Tudi sam je imel rad igrice. }\end{array}$ & 1 \\
\hline 6 & 3 & $\begin{array}{l}\text { Imela je prečudovite zelene oči, polne rdeče ustnice in } \\
\text { naravnost prisrčno karirasto pentljico v laseh. Sullivan je } \\
\text { takoj sklenil da je Marianne mala spogledljivka, njemu pa } \\
\text { je to ustrezalo. Tudi sam je užival v takih igricah. }\end{array}$ & 0 \\
\hline 7 & 4 & $\begin{array}{l}\text { Imela je najlepše zelene oči, polne rdeče ustnice, in nadvse } \\
\text { prisrčno karirasto pentljo, zataknjeno v lase. Sullivan } \\
\text { se je glede nje takoj nekaj odločil - Marianne je bila } \\
\text { spogledljivka, in tako mu je bilo tudi prav. Tudi sam se je } \\
\text { rad igral. }\end{array}$ & 1 \\
\hline 8 & 4 & $\begin{array}{l}\text { Imela je sijajne zelene oči, polne rdeče ustnice in ljubko } \\
\text { majhno karirasto pentljo zataknjeno v laseh. Sullivan ji je } \\
\text { takoj pripel svojo oznako - Marianne je bila mala zapeljivka } \\
\text { in to mu je bilo prav. Tudi on se je rad šel igrice. }\end{array}$ & 0 \\
\hline 9 & 3 & $\begin{array}{l}\text { Imela je najbolj čudovite zelene oči, polne rdeče ustnice } \\
\text { in najbolj srčkano karirasto pentljo v laseh. Sullivan se } \\
\text { je na mestu odločil, da ena stvar o njej drži kot pribito - } \\
\text { Mariannne je bila prava mala nadloga. Sullivana to sploh ni } \\
\text { motilo. Tudi on je se je rad igral. }\end{array}$ & 1 \\
\hline 10 & 3 & I & / \\
\hline
\end{tabular}




\begin{tabular}{|c|c|c|c|}
\hline Študent & Letnik & Prevod SLO 3 & Oblika SLO 3-1 \\
\hline 11 & 4 & $\begin{array}{l}\text { Imela je najbolj čudovite zelene oči, polne rdeče ustnice in } \\
\text { prisrčno majhno karirasto pentljo v laseh. Sullivan je takoj } \\
\text { vedel - Marianne se je rada šopirila, in to ga ni motilo. Tudi } \\
\text { on se je rad igral igrice. }\end{array}$ & 1 \\
\hline 12 & 4 & $\begin{array}{l}\text { Imela je prečudovite zelene oči, polne rdeče ustnice in } \\
\text { najbolj srčkano karirasto pentljico v laseh. Sullivan se je } \\
\text { takoj odločil- Marianne je bila mala zapeljevalka in s tem je } \\
\text { bil zadovoljen. Tudi on se je rad igral takšne igrice. }\end{array}$ & 0 \\
\hline 13 & 4 & $\begin{array}{l}\text { Krasile so jo prekrasne zelene oči, polne rdeče ustnice in } \\
\text { prisrčna mala karirasta pentlja v njenih laseh. Sullivan si je } \\
\text { takoj ustvaril mnenje o Marianne - bila je spogledljivka, kar } \\
\text { mu je bilo všeč, saj se tudi sam oboževal tovrstne igrice. }\end{array}$ & 0 \\
\hline 14 & 4 & $\begin{array}{l}\text { Imela je čudovite zelene oči, polne rdeče ustnice in } \\
\text { prisrčno majhno pentljo iz pleida v laseh. Sullivan je takoj } \\
\text { vedel, da je Marianne mala nagajivka. Nič ni imel proti, saj } \\
\text { je tudi on imel rad take igrice. }\end{array}$ & 0 \\
\hline 15 & 3 & $\begin{array}{l}\text { Imela je neverjetno čudovite zelene oči, polne rdeče } \\
\text { ustnice in naravnost prisrčno karirasto pentljo v laseh. } \\
\text { Sullivan je takoj spregledal, da je Marianne mala koketa, } \\
\text { kar mu je bilo prav. Tudi sam se je rad igral igrice. }\end{array}$ & 0 \\
\hline 16 & 4 & $\begin{array}{l}\text { Imela je najlepše zelene oči, polne rdeče ustnice in zelo } \\
\text { srčkano karirasto pentljico v laseh. Sullivan je bil glede ena } \\
\text { stvari takoj odločen - Marriane je bila ena mala nagajivka, } \\
\text { a to ga ni motilo. Tudi on se je rad igral. }\end{array}$ & 1 \\
\hline 17 & 4 & $\begin{array}{l}\text { Imela je najbolj čudovite zelene oči, polne rdeče ustnice } \\
\text { in prikupno majhno karirasto mašno posajeno v laseh. } \\
\text { Sullivan je takoj prepoznal eno stvar o njej- Marrianne je } \\
\text { bila majhna spogledljivka, a ga to ni motilo. Tudi on se je } \\
\text { rad poigral. }\end{array}$ & 1 \\
\hline 18 & 3 & $\begin{array}{l}\text { Imela je najčudovitejše zelene oči, polne rdeče ustnice, } \\
\text { v laseh pa majhno srčkano karirasto pentljo. Sullivan je } \\
\text { v trenutku prišel do zaključka, da je Marianne majhna } \\
\text { nagajivka. To je bilo prav, saj se je tudi sam rad igral igrice. }\end{array}$ & 1 \\
\hline 19 & 4 & $\begin{array}{l}\text { Imela je nadvse čudovite zelene oči, polne rdeče ustnice, v } \\
\text { laseh pa je imela najbolj srčkan karirast trak. Sullivan se je } \\
\text { že na začetku odločil, da je Marianne majhna navihanka, in } \\
\text { to mu je ugajalo. Tudi on je imel rad igrice. }\end{array}$ & 0 \\
\hline 20 & 4 & $\begin{array}{l}\text { Imela je najbolj čudovite zelene oči, polne rdeče ustnice in } \\
\text { srčkano karirasto pentljo v laseh. Glede nje se je Sullivan } \\
\text { takoj odločil - Marianne je bila koketa in to mu je bilo čisto } \\
\text { všeč. Tudi on se je rad igral. }\end{array}$ & 1 \\
\hline
\end{tabular}

Razpredelnica 9: Prevajanje iz angleščine $v$ slovenščino, tretja naloga, the most gorgeous green eyes $(0=$ pridevniska zgradba brez presežnika,

1 = pridevniska zgradba s presežnikom, 2 = drugačna konstrukcija) 


\begin{tabular}{|c|c|c|c|}
\hline Študent & Letnik & Prevod SLO 3 & Oblika SLO 3-2 \\
\hline 1 & 4 & $\begin{array}{l}\text { Imela je krasne zelene oči, polne rdeče usnice in sladko } \\
\text { karirasto pentljo v laseh. Sullivan se je takoj zaključil nekaj o } \\
\text { njej - Marianne je bila navihana nagajivka, in to mu je bilo } \\
\text { všeč. Tudi sam se je rad igral igrice. }\end{array}$ & 0 \\
\hline 2 & 4 & $\begin{array}{l}\text { Imela je prekrasne zelene oči, polne rdeče ustnice in } \\
\text { srčkano karirasto pentljico v laseh. Sullivanu je nekaj v hipu } \\
\text { postalo jasno - Marianne je spogledljivka, in ni ga motilo. } \\
\text { Tudi on se je rad igral. }\end{array}$ & 0 \\
\hline 3 & 3 & $\begin{array}{l}\text { Imela je prečudovite zelene oči, polne rdeče ustnice in } \\
\text { nadvse prisrčno pentljo v laseh. Sullivan je takoj spoznal } \\
\text { nekaj o njej - Marianne je bila dražljivka in njemu je to } \\
\text { ustrezalo. Tudi on je se je rad igral. }\end{array}$ & 0 \\
\hline 4 & 3 & $\begin{array}{l}\text { Imela je najbolj čudovite zelene oči, polne rdeče ustnice in } \\
\text { prisrčno majhno karirasto pentljo v laseh. Sullivan se je eno } \\
\text { stvar glede nje takoj odločil - Marianne je bila zapeljivka in } \\
\text { to ga ni motilo. Tudi on se je rad igral. }\end{array}$ & 0 \\
\hline 5 & 4 & $\begin{array}{l}\text { Imela je najbolj čudovite zelene oči, polne rdeče ustnice, in } \\
\text { pa zelo srčkano majhno karirasto pentljo v laseh. Sullivan se } \\
\text { je v trenutku odločil - Marianne je bila spogledljivka in to } \\
\text { ga ni motilo. Tudi sam je imel rad igrice. }\end{array}$ & 0 \\
\hline 6 & 3 & $\begin{array}{l}\text { Imela je prečudovite zelene oči, polne rdeče ustnice in } \\
\text { naravnost prisrčno karirasto pentljico v laseh. Sullivan je } \\
\text { takoj sklenil da je Marianne mala spogledljivka, njemu pa je } \\
\text { to ustrezalo. Tudi sam je užival v takih igricah. }\end{array}$ & 0 \\
\hline 7 & 4 & $\begin{array}{l}\text { Imela je najlepše zelene oči, polne rdeče ustnice, in nadvse } \\
\text { prisrčno karirasto pentljo, zataknjeno v lase. Sullivan } \\
\text { se je glede nje takoj nekaj odločil - Marianne je bila } \\
\text { spogledljivka, in tako mu je bilo tudi prav. Tudi sam se je } \\
\text { rad igral. }\end{array}$ & 0 \\
\hline 8 & 4 & $\begin{array}{l}\text { Imela je sijajne zelene oči, polne rdeče ustnice in ljubko } \\
\text { majhno karirasto pentljo zataknjeno v laseh. Sullivan ji je } \\
\text { takoj pripel svojo oznako - Marianne je bila mala zapeljivka } \\
\text { in to mu je bilo prav. Tudi on se je rad šel igrice. }\end{array}$ & 0 \\
\hline 9 & 3 & $\begin{array}{l}\text { Imela je najbolj čudovite zelene oči, polne rdeče ustnice } \\
\text { in najbolj srčkano karirasto pentljo v laseh. Sullivan se } \\
\text { je na mestu odločil, da ena stvar o njej drži kot pribito - } \\
\text { Mariannne je bila prava mala nadloga. Sullivana to sploh ni } \\
\text { motilo. Tudi on je se je rad igral. }\end{array}$ & 1 \\
\hline 10 & 3 & / & I \\
\hline 11 & 4 & $\begin{array}{l}\text { Imela je najbolj čudovite zelene oči, polne rdeče ustnice in } \\
\text { prisrčno majhno karirasto pentljo v laseh. Sullivan je takoj } \\
\text { vedel - Marianne se je rada šopirila, in to ga ni motilo. Tudi } \\
\text { on se je rad igral igrice. }\end{array}$ & 0 \\
\hline 12 & 4 & $\begin{array}{l}\text { Imela je prečudovite zelene oči, polne rdeče ustnice in } \\
\text { najbolj srčkano karirasto pentljico v laseh. Sullivan se je } \\
\text { takoj odločil- Marianne je bila mala zapeljevalka in s tem je } \\
\text { bil zadovoljen. Tudi on se je rad igral takšne igrice. }\end{array}$ & 1 \\
\hline
\end{tabular}




\begin{tabular}{|c|c|c|c|}
\hline Študent & Letnik & Prevod SLO 3 & Oblika SLO 3-2 \\
\hline 13 & 4 & $\begin{array}{l}\text { Krasile so jo prekrasne zelene oči, polne rdeče ustnice in } \\
\text { prisrčna mala karirasta pentlja v njenih laseh. Sullivan si je } \\
\text { takoj ustvaril mnenje o Marianne - bila je spogledljivka, kar } \\
\text { mu je bilo všeč, saj se tudi sam oboževal tovrstne igrice. }\end{array}$ & 0 \\
\hline 14 & 4 & $\begin{array}{l}\text { Imela je čudovite zelene oči, polne rdeče ustnice in prisrčno } \\
\text { majhno pentljo iz pleida v laseh. Sullivan je takoj vedel, da } \\
\text { je Marianne mala nagajivka. Nič ni imel proti, saj je tudi on } \\
\text { imel rad take igrice. }\end{array}$ & 0 \\
\hline 15 & 3 & $\begin{array}{l}\text { Imela je neverjetno čudovite zelene oči, polne rdeče } \\
\text { ustnice in naravnost prisrčno karirasto pentljo v laseh. } \\
\text { Sullivan je takoj spregledal, da je Marianne mala koketa, kar } \\
\text { mu je bilo prav. Tudi sam se je rad igral igrice. }\end{array}$ & 0 \\
\hline 16 & 4 & $\begin{array}{l}\text { Imela je najlepše zelene oči, polne rdeče ustnice in zelo } \\
\text { srčkano karirasto pentljico v laseh. Sullivan je bil glede ena } \\
\text { stvari takoj odločen - Marriane je bila ena mala nagajivka, a } \\
\text { to ga ni motilo. Tudi on se je rad igral. }\end{array}$ & 0 \\
\hline 17 & 4 & $\begin{array}{l}\text { Imela je najbolj čudovite zelene oči, polne rdeče ustnice } \\
\text { in prikupno majhno karirasto mašno posajeno v laseh. } \\
\text { Sullivan je takoj prepoznal eno stvar o njej- Marrianne je } \\
\text { bila majhna spogledljivka, a ga to ni motilo. Tudi on se je } \\
\text { rad poigral. }\end{array}$ & 0 \\
\hline 18 & 3 & $\begin{array}{l}\text { Imela je najčudovitejše zelene oči, polne rdeče ustnice, } \\
\text { v laseh pa majhno srčkano karirasto pentljo. Sullivan je } \\
\text { v trenutku prišel do zaključka, da je Marianne majhna } \\
\text { nagajivka. To je bilo prav, saj se je tudi sam rad igral igrice. }\end{array}$ & 0 \\
\hline 19 & 4 & $\begin{array}{l}\text { Imela je nadvse čudovite zelene oči, polne rdeče ustnice, v } \\
\text { laseh pa je imela najbolj srčkan karirast trak. Sullivan se je } \\
\text { že na začetku odločil, da je Marianne majhna navihanka, in } \\
\text { to mu je ugajalo. Tudi on je imel rad igrice. }\end{array}$ & 1 \\
\hline 20 & 4 & $\begin{array}{l}\text { Imela je najbolj čudovite zelene oči, polne rdeče ustnice in } \\
\text { srčkano karirasto pentljo v laseh. Glede nje se je Sullivan } \\
\text { takoj odločil - Marianne je bila koketa in to mu je bilo čisto } \\
\text { všeč. Tudi on se je rad igral. }\end{array}$ & 0 \\
\hline
\end{tabular}

Razpredelnica 10: Prevajanje iz angleščine v slovenšcino, tretja naloga, the cutest little plaid bow $(0=$ pridevniška zgradba brez presežnika, 1 = pridevniška zgradba s presežnikom, 2 = drugačna konstrukcija)

Iz razpredelnic 9 in 10 lahko razberemo, da je zvezo the most gorgeous (green eyes) 10 študentov prevedlo s pridevniško zgradbo brez presežnika, devet prevodov pa je tudi v slovenščini vsebovalo presežnik. Zvezo the cutest (little plaid bow) je v pridevniški obliki, a brez presežnika prevedlo 16 študentov, s presežnikom pa trije. En študent prevoda te naloge ni oddal. 


\subsection{Povzetek rezultatov}

\begin{tabular}{|c|c|c|c|c|c|}
\hline Naloga & Zgled & $\begin{array}{c}\text { Število prevodov } \\
\text { s pridevniško } \\
\text { zgradbo brez } \\
\text { presežnika }\end{array}$ & $\begin{array}{c}\text { Število prevodov } \\
\text { s pridevniško } \\
\text { zgradbo s } \\
\text { presežnikom }\end{array}$ & $\begin{array}{c}\text { Število } \\
\text { prevodov z } \\
\text { drugačno } \\
\text { konstrukcijo }\end{array}$ & Skupaj \\
\hline 1 & 15 & 4 & 0 & 19 \\
\hline 2 & $\begin{array}{c}\text { a most amazing } \\
\text { female }\end{array}$ & 16 & 3 & 0 & 19 \\
\hline $3-1$ & $\begin{array}{c}\text { the strangest thing } \\
\text { the most gorgeous } \\
\text { (green eyes) }\end{array}$ & 10 & 9 & 0 & 19 \\
\hline $3-2$ & $\begin{array}{c}\text { the cutest (little plaid } \\
\text { bow) }\end{array}$ & 16 & 3 & 0 & 19 \\
\hline Skupaj & & 57 & 19 & 0 & 76 \\
\hline
\end{tabular}

Razpredelnica 11: Prevajanje iz anglešcine v slovenšcino, povzetek rezultatov

Glede na to, da so v tej jezikovni kombinaciji študenti prevajali v svoj materni jezik, bi pričakovali, da bo interferenca manjša ali je sploh ne bo. Napoved se je izkazala za resnično, vendar pa vseeno pomemben del prevodov, 19 od 76 oziroma skupno 25 odstotkov, tudi v slovenščini vsebuje presežnik. Angleški primeri so segali od dveh tradicionalnih rab, a most amazing female s formalno zaznamovano absolutno rabo $\mathrm{z}$ nespecifičnim kazalnikom in the strangest thing, do dveh rab, ki naj bi bili po dosedanjih ugotovitvah (Kavalir 2014) novejši, tj. the most gorgeous (green eyes) s kombinacijo opisnega stopnjevanja in specifičnega kazalnika ter the cutest (little plaid bow) kot pogovorne različice absolutne rabe. Edino opazno odstopanje se pojavlja v primeru zveze the most gorgeous, kjer polovica slovenskih prevodov vsebuje presežnik, vendar je težko ugotoviti, zakaj se ta močna tendenca pojavlja ravno tu.

Raziskava je pokazala, da se pri slovenskih študentih angleščine kljub visoki ravni (C1/ C2) zmožnosti v tujem jeziku pojavljajo pomembni transferni učinki na področju absolutnih in relativnih rab pridevnikov. Čeprav so na splošno absolutne rabe v obeh jezikih mogoče tako na srednji kot na visoki stopnji, obstajajo pomembne razlike v pogostnosti teh strategij v slovenščini oziroma angleščini. Rezultati kažejo, da študenti višjih letnikov anglistike zelo pogosto (ko ne gre za termine, kar v $70 \%$ prevodov) v angleščino prenašajo strategijo absolutnih pridevniških rab na srednji stopnji, čeprav je ta možnost pri maternih govorcih redka. Po drugi strani kar 25 \% prevodov v slovenščino, ki je študentom materni jezik, ohranja angleški absolutni primernik, za katerega je v slovenščini značilna zelo omejena raba. Kljub robustnim rezultatom bi bile zaradi relativno majhnega 
vzorca in posledično predvsem kvalitativnih interpretacij dobrodošle dodatne raziskave področja, hkrati pa je upati, da bo raziskava pozitivno vplivala na nadaljnje poučevanje in usvajanje angleških pridevniških zgradb v Sloveniji.

\section{LITERATURA}

BIBER, Douglas/Stig JOHANSSON/Geoffrey LEECH/Susan CONRAD/Edward FINEGAN (2000) Longman Grammar of Spoken and Written English. Harlow: Longman. BNC. British National Corpus. 10. junij 2016. http://bncweb.lancs.ac.uk.

Commission Regulation (EC) No 497/2003 of 18 March 2003 amending Regulation (EC) No 94/2002 laying down detailed rules for applying Council Regulation (EC) No $2826 / 2000$ on information and promotion actions for agricultural products on the internal market (2003) UL L 74 (20. 3. 2003). 4.

Direktiva Evropskega parlamenta in sveta 96/73/ES z dne 16. decembra 1996 o nekaterih metodah za kvantitativno analizo dvokomponentnih mešanic tekstilnih vlaken (1996) UL L 032 (3. 2. 1997). 1.

Directive 96/73/EC of the European Parliament and of the Council of 16 December 1996 on certain methods for the quantitative analysis of binary textile fibre mixtures (1996) UL L 032 (3. 2. 1997). 1.

European monitoring centre for drugs and drug addiction (2007) 2007 Annual Report: The State of the Drugs Problem in Europe. 10. junij 2016. http://www.emcdda.europa.eu/publications/annual-report/2007.

Evropski center za spremljanje drog in zasvojenosti z drogami (2007) Letno poročilo 2007: stanje na področju problematike drog v Evropi. 10. junij 2016. http://www. emcdda.europa.eu/publications/annual-report/2007.

FidaPLUS. 10. junij 2016. www.fidaplus.net.

HALLIDAY, Michael A. K./Christian M. I. M. MATTHIESSEN (2014) Halliday's Introduction to Functional Grammar. 4. izdaja. London, New York: Routledge.

HEIM, Irene (1999) Notes on superlatives. 10. junij 2016. Semanticsarchive.net. http:// www.semanticsarchive.net/Archive/TI1MTlhZ/Superlative.pdf.

ILC, Gašper (2014) Gramatikalizacija prostorskih členic v angleščini in slovenščini. Slavistična revija 62(3), 309-319.

JAMES, Mark A. (2012) Cross-Linguistic Influence and Transfer of Learning. N. M. Seel (ur.) Encyclopedia of the Sciences of Learning. New York: Springer, 858-61.

JANEŽIČ, Anton (1911) A. Janežičeva slovenska slovnica. 10. izdaja. Celovec: Družba svetega Mohorja

JURKO, Primož (2016) Pragmatic Meaning in Contrast: Semantic Prosodies of Slovene and English. Perspectives [Splet]. DOI:http://dx.doi.org/10.1080/090767 6X.2016.1165262. 
KAVALIR, Monika (2014) Skladenjske in pomenske razsežnosti pridevniških zgradb: doktorska disertacija. Ljubljana, 2014.

KAVALIR, Monika (2017) Prosody and Absolute vs. Relative Uses of English and Slovene Adjectives. Linguistica [v tisku].

KOMAR, Smiljana (2012) An English-Slovene Contrastive Analysis of Discourse Markers. L. Frentiu/L. Punga (ur.), A Journey through Knowledge: Festschrift in Honour of Hortensia Pârlog. Newcastle upon Tyne: Cambridge Scholars Publishing, $150-169$.

LIPOVŠEK, Frančiška (2014) Prepositional Use with the Object-of-Activity Function of the Landmark in English and Slovene. Jezikoslovlje 15(2-3), 153-171.

LOVEC, Nina (2016) Primerjava slovenskega in italijanskega besednega reda v stavkih $\mathrm{s}$ tremi ali dvema elementoma. Vestnik za tuje jezike 7(1), 81-101. DOI:10.4312/ vestnik.7.87-101.

MIKOLIČ, Tamara (2012) A Contrastive Study of Nominalization in the Systemic Functional Framework. Languages in Contrast 12(2), 251-276.

PATTERSON, James (2006) Cross. London: Headline.

PATTERSON, James (2009) Cross. Ljubljana: Mladinska knjiga.

PISANSKI PETERLIN, Agnes (2010) Hedging Devices in Slovene-English Translation: A Corpus-Based Study. Nordic Journal of English Studies 9(2), 171-193.

PLEMENITAŠ, Katja (2015) The Affective Aspect of the Formation of Diminutives in Slovene and English. I. Stramljič Breznik (ur.), Manjšalnice v slovanskih jezikih: oblika in vloga. Maribor: Mednarodna založba Oddelka za slovanske jezike in književnosti, Filozofska fakulteta, 507-516.

QUICK, Amanda (1993) Dangerous. New York: Bantam Books.

QUICK, Amanda (2002) Nevarnost. Ljubljana: Mladinska knjiga.

SCHLAMBERGER BREZAR, Mojca/David LIMON/Ada GRUNTAR JERMOL (ur.) (2015) Contrastive Analysis in Discourse Studies and Translation. Ljubljana: Znanstvena založba Filozofske fakultete.

SICHERL, Eva (2013) Diminutive Nouns and Verbs in Slovene Compared to Their English Equivalents. Slovenski jezik - Slovene Linguistic Studies 9, 145-162.

Skupni evropski jezikovni okvir: učenje, poučevanje, ocenjevanje (2011) Ljubljana: Ministrstvo RS za šolstvo in šport Urad za šolski razvoj. 10. junij 2015. http://www. europass.si/files/userfiles/europass/SEJO\%20komplet\%20za\%20splet.pdf.

TARONE, Elaine (2006) Interlanguage. K. Brown (ur.), Encyclopedia of Language and Linguistics. Boston: Elsevier, 747-51.

TIRKKONEN-CONDIT, Sonja (2002) Translationese - A Myth or an Empirical Fact? Target 14(2), 207-20.

Uredba Komisije (ES) št. 497/2003 z dne 18. marca 2003 o spremembi Uredbe (ES) št. 94/2002 o določitvi podrobnih pravil za uporabo Uredbe Sveta (ES) št. 2826/2000 o informacijskih in promocijskih ukrepih za kmetijske proizvode na notranjem trgu (2003) UL L 74 (20. 3. 2003). 4 
VAUPOT, Sonja (2016) Cohérence discursive en Slovène et en Français: Le rôle des connecteurs en traduction. Vestnik za tuje jezike 7(1), 57-69. DOI:10.4312/vestnik.7.57-69.

VRBINC, Marjeta (2016) English Phraseological Units with an Onomastic Element and Their Translation Equivalents in Slovene. Collegium Antropologicum 40(1), 41-47. ZLATNAR MOE, Marija (2010) Repetition in English vs. Non-Repetition in Slovene: How Different Norms of Good Writing Change the Style of Translated Texts. Slovene Studies 32(1-2), 3-17.

\section{POVZETEK}

Prispevek analizira učinke transferja med slovenščino in angleščino na področju malo raziskanih absolutnih in relativnih rab pridevnikov. Teoretična osnova, ki loči podsistema standarda (notranji, zunanji) in stopnje (osnovna, srednja, visoka), je nadgrajena s praktičnim preizkusom, v kolikšni meri slovenski študenti anglistike, katerih znanje je na ravni $\mathrm{C} 1$ in $\mathrm{C} 2$, na tem področju (neustrezno) prenašajo jezikovne strategije iz enega jezika v drugega. Rezultati kažejo, da študenti, vključeni v preizkus, ob prevajanju iz slovenščine $\mathrm{v}$ angleščino $\mathrm{v}$ veliki večini ohranjajo absolutne primernike, čeprav so ti v angleščini veliko redkejši. Po drugi strani tudi ob prevajanju v materni jezik znaten del študentov ohranja absolutne presežnike, ki so produktivna strategija v angleščini, v slovenščini pa se pojavljajo le redko.

Ključne besede: angleščina, slovenščina, kontrastivna analiza, pridevniške zgradbe, transfer

\section{ABSTRACT}

\section{Transfer Effects in Absolutely and Relatively Used Adjectives among Slovene Students of English}

The article analyses transfer effects between Slovene and English with regard to the little researched area of absolute and relative uses of adjectives. The practical test of the extent to which Slovene students of English (levels C1 and C2) exhibit (negative) transfer of linguistic strategies between the two languages builds on a theoretical account of adjectival use that distinguishes between the subsystems of standard (internal, external) and degree (base, median, high). The results show that in translating from Slovene into English, the great majority of the students tested retain absolute comparatives, even though they are much less common in English. On the other hand, a significant proportion of students also keep absolute superlatives when translating into their mother tongue, even though this is a productive strategy in English and only rarely used in Slovene.

Key words: English, Slovene, contrastive analysis, adjectival constructions, transfer 